Paweł Bachmat

\title{
Wykonywanie pracy przez skazanego ${ }^{1}$
}

\author{
Performance of labour by the convicted person
}

According to the author of the opinion, in the Polish criminal law system such a role is played by the penalty of restriction of liberty. In the catalogue of penalties it holds a second rank in terms of severity. The author emphasizes that the penalty of restriction of liberty may consist of performing unpaid, controlled work for social purposes. On the other hand, the penalty of restriction of liberty may consist of deducting a part of remuneration for ordinary work and transferring this amount to funding a social purpose indicated by a court.

Keywords: ECPRD, labour, prisoners

Zdaniem autora opinii w polskim systemie prawa karnego rolę taką odgrywa kara ograniczenia wolności. W katalogu kar zajmuje ona drugie miejsce pod względem dotkliwości. Autor podkreśla, że kara ograniczenia wolności może polegać na wykonywaniu nieodpłatnej, kontrolowanej pracy na cele społeczne. Z drugiej strony kara ograniczenia wolności może polegać na potrącaniu części wynagrodzenia za zwykłą pracę i przekazaniu tej kwoty na cel społeczny wskazany przez sąd.

Słowa Kluczowa: ECPRD, praca, więźniowie

Asystent w Instytucie Wymiaru Sprawiedliwości • Instytut Wymiaru Sprawiedliwości, WARSZAWA, POLSKA •

pawel.bachmat@sejm.gov.pl • https://orcid.org/0000-0003-3511-5425

In response to ECPRD Request No. 4162 regarding the issue of so called hard labour the Bureau of Research provides the following information. However, at the beginning it should be stipulated that the term hard work can be misleading. In the information presented here, the term hard work will be understood in accordance with the meaning given to it in ECPRD: 1) as a kind of punishment imposed on the perpetrator of the crime or 2) a particular circumstance accompanying the execution of a prison sentence.

1 Hard labour as a penalty (ECPRD request no. 4162) - informacja sporządzona 18 września 2019 r. w ramach współpracy w Europejskim Centrum Badań Parlamentarnych i Dokumentacji (The European Centre for Parliamentary Research and Documentation); BAS-WAP 1782/19. 4) s. 179 
- 1. Can someone who has committed a crime be sentenced to community service as a penalty? Community service refers to non-salaried work for a certain number of hours which the convicted person has to carry out in his or her spare time.

In the Polish criminal law system, this role is played by the penalty of restriction of liberty. In the catalog of penalties specified in the Polish Penal Code, it ranks second in terms of severity. In accordance with art. 32 of the Penal Code, the catalog of penalties that the court may impose on the perpetrator of the crime is as follows:

1) fine;

2) restriction of liberty;

3) imprisonment;

4) 25 years imprisonment;

5) life imprisonment.

The order of these penalties is not accidental. The legislator defined it in such a way that it began the catalog of penalties with the mildest penalty (fine). The penalty of restriction of liberty is therefore the second penalty in terms of severity.

The penalty of restriction of liberty may be exercised in three ways (art. 34 $\$ 1 \mathrm{a}-1 \mathrm{~b}$, art. $35 \$ 1-2$ of the Penal Code). The choice of a particular form of execution of a this penalty in relation to a specific offender belongs to the court which decides this matter in the judgment.

First of all, the penalty of restriction of liberty may consist of performing unpaid, controlled work for social purposes. Such work is performed from 20 to 40 hours on a monthly basis. It should be recognized that this form is the closest to the community service model, to which reference is made in ECPRD Request (criterion for performing unpaid work).

Secondly, the penalty of restriction of liberty may consist of deducting from $10 \%$ to $25 \%$ of remuneration for work on a monthly basis for the social purpose indicated by the court. A deduction of remuneration for work may be imposed on the employed person. During the period for which the deduction has been imposed, the convict may not terminate the employment relationship without the court's consent.

Thirdly, the execution of a restriction of liberty may be complex. Then the convicted person is obliged to perform unpaid, controlled work for social purposes in one place, and moreover, from his remuneration for work in another place is deducted from $10 \%$ to $25 \%$ on a monthly basis for social purposes.

The Penal Code stipulates that the penalty of restriction of liberty generally lasts for one month up to 2 years. It is measured in months and years. However, a special act of law may specify a different duration of this penalty (Article $34 \$ 1$ of the Penal Code). 
It should be added that while executing the penalty of restriction of liberty, regardless of the form of exercising it, the convicted person is obliged to: 1) not to change the place of permanent residence, 2) provide explanations regarding the course of serving the sentence (art. $34 \S 2$ of the Penal Code).

In addition, when imposing a penalty of restriction of liberty, the court may impose additional obligations on the convict from the list below (art. $34 \S 3$ of the Penal Code):

1) payment of a cash benefit to the Fund for Victim Aid and Post-penitentiary Assistance,

2) apologizing to the victim,

3) performance of his obligation to provide for the maintenance of another person (maintenance obligation),

4) performing gainful employment, studying or preparing for a profession,

5) refraining from alcohol abuse or using other intoxicants,

6) undergoing addiction therapy,

7) to undergo therapy, in particular psychotherapy or psychoeducation,

8) participation in corrective and educational actions,

9) refraining from staying in certain environments or places,

10) refraining from contacting the victim or other people in a certain way or approaching the victim or other people.

The Penal Code stipulates that the time and manner of performance of these additional obligations are determined by the court after hearing the convict, and the imposition of the obligation mentioned in points 6 and 7 requires the convict's consent.

- 2. Is there any possibility, within the framework of serving a prison sentence, to force prisoners to perform hard labour? If so, what type of labour is it? Hard labour refers to labour that is carried out in conjunction with deprivation of liberty and which the convicted person is required to carry out. The work in question should be nonsalaried.

According to the model for employing convicts adopted in the polish Executive Penal $\mathrm{Code}^{2}$, a person sentenced to imprisonment may perform work while serving a sentence. Therefore, the Executive Penal Code provides that convicts are guaranteed work, but as far as possible. The convicted person is employed on the basis of a referral to work or the convicted person is allowed to perform gainful employment under an employment contract, mandate contract, contract for specific work, contract of outwork or other legal basis (article $120 \$ 1$ and 2 of the Executive Penal Code). However, in this situation the rule is that the work

2 The Executive Penal Code of the 6th June 1997, Journal of Laws 2019, item 676, consolidation act as amended). 
performed by the convict is payable. The principles of remuneration for work are established in an agreement concluded by the director of the prison or in a contract concluded by the convict. When referring a convicted person to administrative and order work in the penal institution, the remuneration for work is determined by the director of this institution (Article $123 \$ 1$ of the Executive Penal Code).

An exception to this model is the situation when the convicted person performs work without remuneration (art. 123a of the Executive Penal Code). This mainly applies to:

- cleaning and auxiliary works performed for the benefit of organizational units of the Prison Service,

- as well as work for social purposes for: 1) local government, 2) entities for which the commune, poviat or voivodship body is a founding body, 3) state or local government organizational units, 4) commercial law companies with exclusive participation of the Treasury or commune, poviat or province

It should be emphasized that the convicted person carries out these types of work on his own initiative or with written consent. In addition, unpaid work may not exceed 90 hours on a monthly basis.

Moreover, the convicted person may work for free for institutions or organizations representing the local community, and in educational establishments, youth educational centers, youth sociotherapy centers, medical entities within the meaning of the provisions on medical activity, social assistance organizational units, foundations, associations and other public institutions or organizations that provide charity. Then a written consent or application for permission to perform such work is also required. It is directed to the Director of the penitentiary institution.

Also for the purpose of apprenticeship to perform work in the future, a convict, with his written consent, may be allowed to perform unpaid work in prison establishments, for a period not longer than 3 months.

In each case cited above rewards may be awarded to the convict for unpaid work. 